\title{
Międzynarodowa Konferencja Studenckich Kół Naukowych - Siedlce 23-24 września 2003 r.
}

Kiedy to w latach osiemdziesiątych XIX wieku zaczęły powstawać pierwsze koła naukowe na polskich uczelniach nikt nie mógł wtedy przypuszczać, że będą cieszyły się one dużym zainteresowaniem studentów i że przetrwaja aż do dnia dzisiejszego. Na poczatku działalności zrzeszaly one tylko elitę naukową, która potem stawała się kadrą danej uczelni. Dziś oto w kołach naukowych aktywnie uczestnicza „wszyscy studenci”, którzy odczuwają taką potrzebę i chcą robić coś więcej oprócz zajęć w ramach toku studiów, a przede wszystkim dla siebie i nauki. Potwierdzeniem tak intensywnego rozwoju jest to, ze w latach następnych, zwłaszcza siedemdziesiątych kolejnego wieku nastapił ilościowy rozwój kół naukowych i prawie na każdym uniwersytecie powołano Rady Kół Naukowych, których celem było ,rozstrzyganie sporów między organizacjami studenckimi oraz podział środków na studencką działalność, przeznaczanych przez uczelnię i wydzialy"' . Krótkotrwałe załamanie w rozwoju kół naukowych występowało w następnym dziesięcioleciu, gdyż koła te były upolitycznione, a ruch studencki praktycznie zaginął. Trzeba było czekać, aż do lat transformacji ustrojowej, a konkretnie do roku 1994. Wtedy to ponownie przystappiono do wznowienia działalności kół naukowych. Oto „wielki dyskurs nad przemianami w edukacji, zapoczątkowany pod koniec lat osiemdziesiątych ubiegłego stulecia"2, dziś m.in. dzięki przystąpieniu Polski do Unii Europejskiej - znacznie nabiera na sile. Koła naukowe są ofertą dla młodzieży, która dzięki temu ma możliwość samorealizacji i rozwijania pasji.

Wydawać by się mogło, że dziś, gdy głównym celem młodych ludzi jest pościg za pieniędzmi, dobra praca i najlepszym miejscem w hierarchii społecznej - mało kto chce realizować się w działalności naukowej, nie gwarantujacej wysokich zarobków. Okazuje się, że można znaleźć studentów przedsiębiorczych, pragmatycznych, charyzmatycznych, zdolnych i rozwijających swój potencjał intelektualny, zainteresowania oraz tożsamość. Dlatego do motywów wstępowania do kół naukowych należa: „,chęć podniesienia kompetencji merytorycznych i naukowych, możliwość podjęcia działalności, perspektywa zawarcia nowych znajomości, wizja wyjazdów na konferencje, ewentualność kontaktu z autorytetami nauki" ${ }^{3}$. Obecnie osią konstruowania działalności kół naukowych - w większości przypadków - zdaje się być już nie wizja, a fakt wstapienia Polski do Unii Europejskjej. Dlatego też, aby wyjść naprzeciw oczekiwaniom studentów i pracowników naukowych z kraju i zza granicy została zorganizowana już po raz drugi w dniach 23-24 września 2003 roku, w Akademii Podlaskiej w Siedlcach, Druga Międzynarodowa Konferencja Studenckich Kół Naukowych, której tematem byl "Studencki Ruch Naukowy w aspekcie integracji z Unia Europejska". Konferencja prowadzona była w 4 sekcjach: nauki humanistyczne, nauki ekonomiczne, nauki przyrodnicze, nauki ścisłe. Jak twierdzi Kazimierz Jankowski podział ten wynikał z faktu, iż w Akademii Podlaskiej „studenci mają możliwość zdobywania wiedzy w różnych dziedzinach - począwszy od nauk przyrodniczych poprzez humanistyczne, ekonomiczne, aż do nauk ścisłych"4. Celem było zaprezentowanie dotychczasowego dorobku naukowego studenckich kół naukowych i wskazanie perspektyw ich dalszego rozwoju oraz wspólne ustalenie miejsca tej działalności w krajach europejskich. Uczestnicy przedstawili referaty dotyczace jakiegoś problemu badawczego. Zdarzało się, że promowano same Koła Naukowe.

W konferencji brało udział bardzo dużo studentów. Byli przedstawiciele takich uczelni, jak: Akademia Podlaska (dr A. Bobryk; Koło Logopedyczne; Koło Naukowe Młodych Pedagogów, Koło Naukowe Polonistów, Koło Naukowe Regionalistów; SKN Etnosocjologów), Uniwersytet Opolski

1 Adres internetowy: http://venus.ci.uw.Edu.pl/ rubikon/Nr8-9/rada.htm

2 B. Sliwerski, Współczesne zagrożenia dla edukacji alternatywnej w Polsce, [w:] Kształcenie wczesnoszkolne na przelomie tysiacleci, red. W. Puślecki, Warszawa 2000, s. 114.

3 M. Ganczarska, Motywy działania studentów w kolach naukowych w dobie integracji z Unią Europejska, [w:] Młodzież akademicka a współczesna nauka, red. K. Jankowski, Siedlce 2003, s. 40.

4 Tamże, s. 5. 
(Naukowe Koło Terapeutów), Akademia Techniczno-Rolnicza w Bydgoszczy (Koło Naukowe Mechaników), Akademia Świętokrzyska (SKN Młodych Pedagogów, mgr R. Miszczuk), Państwowa Wyższa Szkola Zawodowa - Gorzów Wielkopolski (dr B. Orłowska, Koło Naukowe Pedagogów), Collegium Europaeum Gnesnense (Koło Naukowe Europeistów), Akademia Bydgoska (Koło Naukowe Bibliotekoznawców, dr A. Chlewicka), Wyższa Szkoła Zawodowa w Krośnie (Koło Naukowe Germanistów), Uniwersytet Państwowy w Brześciu, Akademia Pedagogiczna w Krakowie (Koło Artystyczno - Naukowe), Politechnika Krakowska (mgr inż. arch. Farid Nassery), Uniwersytet Ślaskj - filia w Cieszynie (mgr S. Żak; mgr K. Czerwińska), Minsk State Linguistic University Belarus (mgr O. Kasperovich ), Uniwersytet Państwowy w Brześciu (Ż. Siedun), Universitas Studiorum Polona Vilnensis w Litwie (Stowarzyszenie Naukowców Polaków Litwy; dr J. Szostakowski), Uniwersytet Państwowy w Brześciu (H. Żmińko), Uniwersytet im. Adama Mickiewicza (SKN Historii Kultury i Edukacji). Większość z nich przyjechała na dzień przed rozpoczęciem oficjalnych uroczystości. Dawało to m.in. możliwość zapoznania się ze struktura miasta i uczelni, zakwaterowania się w akademiku oraz załatwienia kwestii formalnych (np. dotyczących bloczków delegacyjnych). Przyjazd tak wielu osób wprowadził pewną dezintegrację w mieście i zdziwienie wśród mieszkańców, ale mimo tego wszyscy zostali przyjęci bardzo życzliwie. Często też sami przyjezdni okazywali się „zagubieni” w tej nowości sytuacji, gdyż dotarcie do akademika $z$ dworca PKP należało chyba do jednych z najtrudniejszych i największych wyzwań tego pobytu.

Oficjalna część konferencji rozpoczęła się kolejnego dnia o godzinie 10.00 uroczystym przywitaniem młodych naukowców przez prof. dr hab. K. Jankowskiego, prorektora do spraw dydaktyki Akademii Podlaskiej i przedstawieniem się przez pozostałych organizatorów. Następnie odbyły się obrady plenarne, w których udział brali wszyscy uczestnicy spotkania. Tu swoje wystapienie miał prof. dr hab. J. Jaroń z referatem pt. „Typologia studentów we współczesnej Polsce” i dr M. Richta z referatem pt. „Polska w aspekcie integracji z Unia Europejska”. W godzinach $11.30-12.00$ prowadzono twórcze rozmowy w kuluarach. Również w tym czasie była możliwość bliższego poznania się osób ze wszystkich sekcji. Dużym zainteresowaniem cieszyli się goście, którzy przyjechali zza granicy, głównie tej wschodniej. Jak się w czasie dyskusji okazało poważny problem stwarzała bariera językowa, szczególnie w przypadku osób posługujących się językiem rosyjskim, gdyż - w moim przekonaniu - Polacy coraz rzadziej podejmują się nauki tego języka. Mimo tych przeciwności ciekawym zjawiskiem była wymiana informacji o kulturach narodów europejskich oraz opinii dotyczących wstapienia „,nowych” krajów do państw Zjednoczonej Europy - co zresztą było jednym z celów tej konferencji.

Dalszy ciag obrad odbył się z podziałem na sekcje, gdzie młodzi naukowcy prezentowali swoje referaty. Przewodniczącym sekcji humanistycznej był dr A. Bobryk i dr A. Gomułka - z jednej strony - pracownicy naukowi Akademii Podlaskiej - z drugiej natomiast - główni organizatorzy. Jak można było się przekonać, tematyka wystapień była różnorodna, co wskazywało na to, że studenci interesuja się wieloma zjawiskami badawczymi. Zauważył to również prof. dr hab. Kazimierz Jankowski, który stwierdzil, że „tak duża różnorodność naukowego podejścia do prowadzonych badań wskazuje na wielki potencjał intelektualny drzemiacy w młodym pokoleniu, wchodzącym dopiero $w$ świat nauki, będącym szansa kreowania przyszłości" 5 . Niewątpliwie słowa te zostały potwierdzone w dobrej jakości merytorycznej wystapień studentów. Warto tu podać przykłady kilku referatów: Rola komputerów we współczesnej edukacji; Model oświaty XXI w.; Sztuka ludowa jako problem badawczy; Działalność Kościoła Zielonoświatkowego w Polsce; Monastery na Podlasiu i Mazurach; Mniejszość prawosławna i białoruska $w$ internecie na terenie Polski; Idea klas integracyjnych w zjednoczonej Europie. Do jednego z najciekawszych a zarazem niekonwencjonalnych i wyjatkowych wystapień - w moim przekonaniu - należał referat pt. „Smoki w architekturze Krakowa” mgr inż. arch. Farida Nassery z Politechniki Krakowskiej. Autor rozpoczał od przedstawienia krótkiego rysu historycznego, w którym to smoki towarzyszyły człowiekowi we wszystkich niemal kulturach, potem przeszedł do grupy ich

\footnotetext{
s Tamże, s. 5.
} 
tępicieli (np. święci, rycerze) oraz legend i mitów dotyczące smoków. Na końcu autor przy pomocy środków multimedialnych zaprezentował ciekawe zdjęcia z różnymi interpretacjami wizerunku smoka oraz miejscami występowania ich $w$ architekturze Krakowa (jest kilkadziesiat). Sa one wykonane np. z kamienia, kute lub odlewane z metalu, blachy, a do najsłynniejszych pomników należy ten u stóp Wawelu. Również w tej części swoje wystąpienie miały studentki Uniwersytetu im. Adama Mickiewicza w Poznaniu: Olga Zagłoba z referatem pt. „Sytuacja kobiet w świetle ustawodawstwa unijnego" i Barbara Laskowska z referatem pt. „Kobieta we współczesnej Polsce”. Wystapienia te zostały bardzo przychylnie i życzliwie przyjęte, choć uchodziły za kontrowersyjne w swojej treści, a same autorki uznane zostały za feministki, mimo tego, iż nie było to ich zamiarem. Wyciagajac pozytywne wnioski można stwierdzić, że wystapienia te na pewno nie były nikomu obojętne. Następnie po oficjalnych przemówieniach rozpoczęła się krótka dyskusja, a potem podsumowanie tej części obrad.

Pierwszy dzień konferencji zakończył się uroczystą kolacją. Tutaj też zaproszeni goście mieli okazję i możliwość poznania wszystkich uczestników konferencji oraz wykładowców Akademii Podlaskiej. Można było porozmawiać i zadać pytania dotyczące przedstawionych referatów, wymienić się spostrzeżeniami i uwagami, wyjaśnić wszelkie watpliwości. $Z$ kolei, osoby uzdolnione muzycznie miały możliwość wykazania się swoim ,głosem" i talentem, dlatego też nie zabrakło kilku chętnych, którzy zaczęli śpiewać na forum, aby uprzyjemnić pozostałym uczestnikom wieczór. Było też wiele życzliwych dedykacji, często dla nowo poznanych osób - reprezentantów z różnych kół naukowych. Spotkanie trwało do późnych godzin wieczornych.

Drugiego dnia uczestnicy spotkania pojechali na wycieczkę turystyczną do Janowa Podlaskiego. Tu zwiedzano stadninę koni, Park Krajobrazowy i kolegiatę. Ten dzień okazał się nie mniej ciekawy od pierwszego, gdyż wniósł do biografii studentów i pracowników naukowych miłe wspomnienia o pięknych krajobrazach Ziemi Podlaskiej. Dwudniowy zjazd zakończyl się po południu wspólnym obiadem. Wybrane referaty zostały opublikowane w materiałach konferencyjnych: red. K. Jankowski, Młodzież akademicka a współczesna nauka, Siedlce 2003.

Mam nadzieję, że kontakty nawiązane w czasie trwania konferencji zaowocuja dalsza wymiana myśli i współpraca badawcza.

Barbara Laskowska

\section{Inauguracja roku akademickiego 2004/2005 w Collegium Europaeum Gnesnense - 11 października 2004}

11 października 2004 roku w Collegium Europaeum Gnesnense odbyło się uroczyste zakończenie pierwszego etapu budowy CEG oraz inauguracja roku akademickiego 2004/2005. Swoją obecnościa uświetnili uroczystość m. in.: JM Rektor UAM prof. dr hab. Stanisław Lorenc, Metropolita Gnieźnieński ks. abp Henryk Muszyński, b. Rektor prof. dr hab. Stefan Jurga, poseł Tadeusz Tomaszewski, starosta gnieźnieński Jacek Kowalski, prezydent Gniezna Jaromir Dziel, zastępca prezydenta Gniezna Robert Andrzejewski, Rektor Wyższego Seminarium Duchownego ks. prof. dr hab. Bogdan Czyżewski, Dziekan Wydziału Studiów Edukacyjnych prof. dr hab. Wiesław Ambrozik, Prodziekan WSE prof. dr hab. Dorota Żołądź-Strzelczyk, Prodziekan Wydziału Filologii Polskiej i Klasycznej prof. dr hab. E. Kasprzak.

O godz. 9.00 w hallu CEG, po odśpiewaniu Gaude Mater przez chór Schola Cantora z Kalisza pod batuta prof. dr hab. Andrzeja Ryłko, JM Rektor UAM prof. dr hab. Stanisław Lorenc przywitał wszystkich zebranych. W przemówieniu podkreślił nowatorstwo CEG, przedstawił dotychczasowe etapy budowy oraz ich konstruktorów i wykonawców, uwydatnit rolę, jaka w kształtowaniu Collegium 